"The growth-IPRs nexus in OPEC member countries: an empirical investigation"

\begin{tabular}{|c|c|c|}
\hline AUTHORS & Nasser Al-Mawali & \\
\hline ARTICLE INFO & $\begin{array}{l}\text { Nasser Al-Mawali (2016). The gi } \\
\text { an empirical investigation. Inves } \\
\text { 13(2), 92-98. doi:10.21511/imfi.1 }\end{array}$ & $\begin{array}{l}\text { n OPEC member countries: } \\
\text { t and Financial Innovations, }\end{array}$ \\
\hline DOI & http://dx.doi.org/10.21511/imfi.13 & \\
\hline RELEASED ON & Friday, 03 June 2016 & \\
\hline JOURNAL & "Investment Management and Fi & \\
\hline FOUNDER & LLC “Consulting Publishing Con & erspectives" \\
\hline & & $\begin{array}{l}\text { ニE } \\
\text { =Ẽ }\end{array}$ \\
\hline NUMBER OF REFERENCES & NUMBER OF FIGURES & NUMBER OF TABLES \\
\hline 0 & 0 & 0 \\
\hline
\end{tabular}

(C) The author(s) 2022. This publication is an open access article. 
Nasser Al-Mawali (Oman)

\title{
The growth-IPRs nexus in OPEC member countries: an empirical investigation
}

\begin{abstract}
This study employs a parsimonious model of economic growth to investigate the impact of intellectual property rights (IPRs) protection on the economic growth of Organization of the Petroleum Exporting Countries (OPEC) member countries. The growth model is estimated in the context of the Hausman-Taylor estimation technique in an annualized panel data framework. The principal finding suggests that IPRs per se are not an important factor in explainingthe economic growth of OPEC member countries. However, the interaction between IPRs and trade has exerted a positive and significant impact on the economic growth of OPEC member countries.
\end{abstract}

Keywords: intellectual property rights, economic growth, OPEC.

JEL Classification: O49, O53, K42.

\section{Introduction}

Economists have long been interested in the Organization of Petroleum Exporting Countries (OPEC) with a view to better understanding the world oil market. As a result, there is an enormous number of studies on OPEC member countries covering various issues, such as OPEC's market structure (e.g., Gulen, 1996; Liu, Ji and Fan, 2013), oil consumption (Mohn and Osmundsen, 2008; Lean and Smyth, 2009), returns on investment in oil (Boone, 2001) and oil exhaustion (Karbassi, Abdul and Abdollahzadegh, 2007; Hook and Aleklett, 2008; Tsoskounoglou, Ayerides and Tritopoulos, 2008). However, apart from oil as a source of growth, little attention has been paid to examining other possible sources of economic growth in OPEC countries. Examples of studies that have looked at oil as a source of economic growth are those by Buno and Sachs (1982), Ghalayini (2011), Abubaker, Agayey and Ilkan (2013), and James (2015).

In fact, existing literature has identified a number of engines of economic growth, none of which has received as much attention as the role of innovation in economic growth (Hudson and Minea, 2013). The attention paid by economists to the role of IPRs in economic growth issues has recently been revived by the development of new growth theories, especially endogenous growth theory, and this attention has increased because of the ongoing negotiations to ratify the World Trade Organization's (WTO) Agreement on Trade-Related Aspects of Intellectual Property Rights (TRIPS), which has acted as a catalyst to bring discussions of IPRs to the forefront of policy debates.

What motivated the current study is that, despite the presence of substantial research on the impact of oil on economic growth, the understanding of the role

(C) Nasser Al-Mawali, 2016.

Nasser Al-Mawali, Ph.D., Sultan Qaboos University, Oman. of IPRs in the economic growth of the OPEC countries remains under researched. Thus, it will be interesting to examine whether IPRs play any role in the economic growth of the OPEC countries.

Given this gap in the literature, the objective of this study is to estimate and analyze the role of the level of IPRs on the economic growth of the OPEC countries.

This research has some limitations, which should be noted. It is worth mentioning that the IPRs measure used in this research is based on the updated version of the Ginarte and Park index (Park, 2008) and it is limited to only some of the OPEC member states. Furthermore, the time span of the study is limited by the data availability of IPRs, which is published every five years and spans the period 1960-2010.

The paper is organized as follows. The macroeconomic structure of OPEC member states and the level of IPRs is presented in Section 1. Section 2 reviews the relevant literature on IPRs and economic growth. The methodological framework and data descriptions are detailed in Section 3. Section 4 presents the model estimation and empirical results. The concluding remarks are presented in the Final Section of the paper.

\section{Macroeconomic structure of OPEC member states and level of IPRs}

It is important to examine some of the key macroeconomic characteristics of OPEC member states in relation to the level of IPRs. The present study attempts to graphically examine some key macroeconomic indicators in relation to the level of IPRs, as shown in Figure 1. The figure shows that the relationship between IPRs and economic growth for the selected OPEC members is ambiguous, which is in line with existing literature, as will be explained in the following section. The figure shows that there is no clear relationship between the level of IPRs in OPEC member states and the volume of 
exports. This is in line with economic theory, which tells us that the impact of IPRs on trade is ambiguous (Smith, 1999). This is because strong foreign IPRs protection simultaneously increases trade via market expansion, and decreases it via market power. The market expansion effect is defined as the case in which strong foreign IPRs protection expands export markets by ensuring exclusive rights to sell the protected exports, while the market power effect is defined as the case when strong foreign IPRs protection reduces exports by granting a temporary monopoly power over the protected good (Maskus and Penubarti, 1995; Smith, 1999).

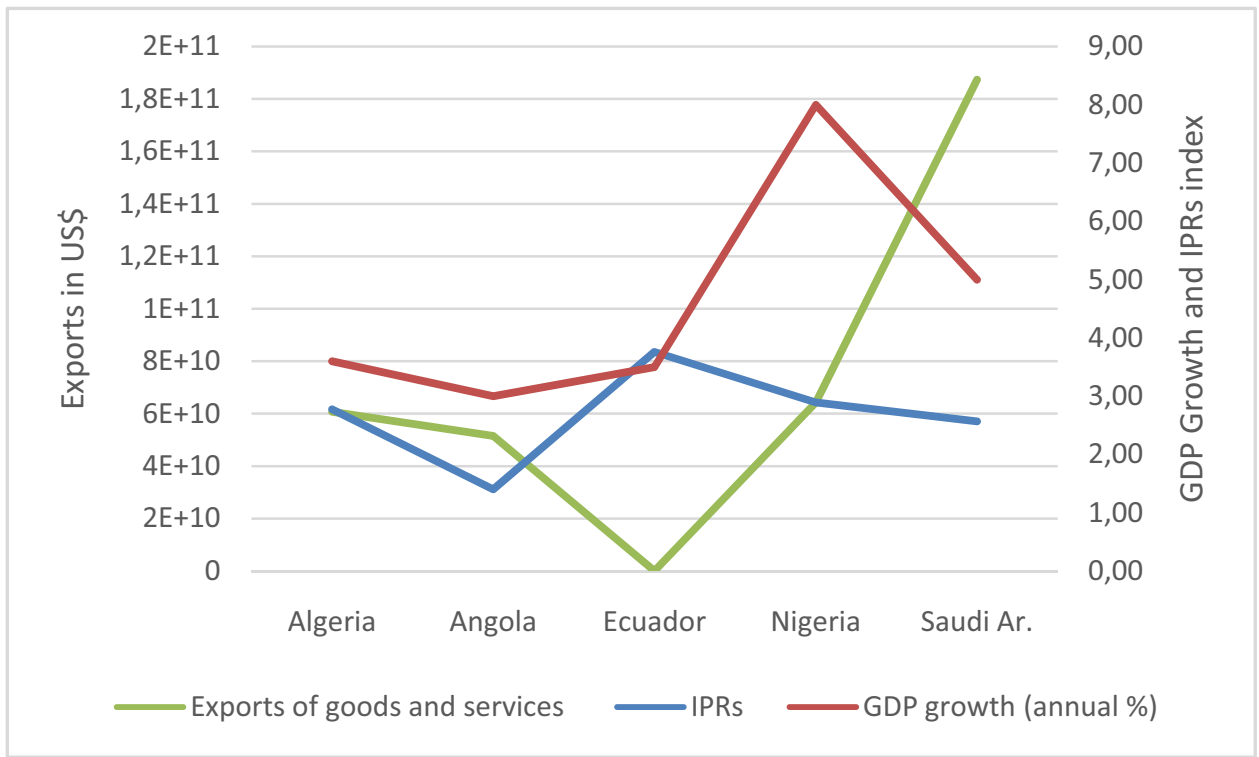

Source: Author's own construction, data from World Bank (2014).

Fig. 1. Relationship between some of the key macroeconomic indicators and IPRs for selected OPEC members in 2010

\section{Review of relevant literature}

The relationship between IPRs and economic growth is quite complex from a theoretical point of view. On the one hand, there are theoretical arguments suggesting that stronger IPRs can have positive effects on development. On the other hand, there are arguments against stronger IPRs (Hassan, Qaqub and Diepeveen, 2010). In general, the existing empirical and theoretical literature on the relationship between the strength of a country's IPRs and its rate of growth is still inconclusive (Gould and Gruden, 1996; Koléda, 2005; Falvey, Foster and Greenaway, 2006; Horii and Iwaisako, 2007; Furukawa, 2007; Dinopoulos and Segerstrom, 2010).

The new growth theory emphasizes the role of innovation in economic growth. The theoretical work of Romer (1990), Grossman and Helpman (1991), Rivera-Batiz and Romer (1991), and Helpman (1993) indicated that the rate of economic growth depends upon the rate of innovations and the stock of knowledge. Following the work of Helpman (1993), there have been many studies of how IPRs protection affects economic growth. These studies have concluded that tightening IPRs enhances innovation and economic growth. An example of a theoretical study that concluded that IPRs promote economic growthis the research by Kwan and Lai (2003), which incorporated the exogenous imitation rate into a lab-equipment version of variety expansion models to examine how IPRs protection affects welfare and growth. Iwaisako and Futagmi (2003) showed that extending patent length enhances economic growth in the variety expansion model of Romer (1990). These models concluded that strengthening IPRs always enhances economic growth.

On the other hand, strong IPRs protection need not always yield higher levels of innovation and economic growth, because giving innovators too much protection may limit the spread of new ideas and lead to monopoly (Maskus, 2000). An example of a study that did not support the role of IPRs in economic growth on a theoretical basis is the research by Horii and Iwaisako (2007), who found it difficult to find a positive relationship between IPRs protection and the growth rate. Gould and Gruden (1996) also identified a"weak" relationship between IPRs protection and the growth rate. Koléda (2005) showed that the effect of patent novelty requirements on growth can be inverse U-shaped, which implies that tightening IPRs protection dampens economic growth for a range of stronger novelty requirements. The recent work of Furukawa (2007), which investigated the effects of IPRs protection on economic growth in a variety expansion model of endogenous growth, concluded that IPRs protection may not enhance economic 
growth in an endogenous growth model with costless imitation, such that "stronger is always better" is incorrect.

The empirical evidence on the role of IPRs in economic growth has also revealed mixed results, confirming the conflicting theoretical predictions. Empirical studies concluding that IPRs have a positive effect on economic growth include Falvey, Foster and Greenaway (2006), Gould and Gruden (1996), Ginarte and Park (1997), Thompson and Rushing (1999), Kanwar and Evenson (2003), and, more recently, research by McLennan and Le (2011), Andrés and Goel (2011), Sattar and Mahmood (2011), and Eicher and Newiak (2013). The study by Eicher and Newiak (2013) documented that unenforced IPRs exert no effect on development, and, instead, it is the level of enforced IPRs that may cause development.

A recent study by Hudson and Minea (2013) concluded that the effect of IPRs on innovation is more complex than previously thought, displaying important nonlinearities depending on the initial levels of both IPRs and per capita GDP.

Other empirical works on IPRs and economic growth are either skeptical about or completely against the positive effect of IPRs. Examples include a study by Lerner (2009), who found little positive impact of protecting patents on innovations and economic growth. Boldrin and Levine (2009) argued that protecting innovative activities is only important for the "discovery" period, and concluded that, in the long run, protecting IPRs might be damaging because of diminishing returns and the extent to which less developed economies can imitate the imported products. A study by $\mathrm{Wu}$ (2010) observed that there is no consensus in the literature on the relationship between IPRs protection and economic growth, because the relationship relies on the development level of the country, which imposes different necessities of innovation and imitation that affect the impact of IPR protection. Samuel (2011) found that the impact of IPRs on economic growth is actually negative for the countries of Sub-Saharan Africa (SSA), because most innovation in SSA may be imitative or adaptive in nature; thus, providing stronger IPRs may protect foreign firms at the expense of domestic firms of SSA.

In summary, while the existing literature highlights the potential importance of IPRs protection for innovation and growth, it has also suggested that there could be important differences in the relationship between countries depending on, inter alia, country-specific determinants of economic growth, as well as the channels through which technology may have been transferred (e.g., trade, licensing, FDI).

\section{Methodological framework and data}

3.1. The model. We employ the model used by $\mathrm{Wu}$, Cai and Jefferson (2013) in their study of how trade and IPRsare linked to long-run economic growth. The model is based on the fundamentals of growth theory. The model starts with the intensive form of a Cobb-Douglas production function:

$q_{i t}=A_{i t} K^{\alpha}{ }_{i t}$,

where $q_{i t}$ is GDPP in country $i$ and year $t$; $K$ is the capital-labor ratio and $A$ is the level of labor productivity. According to Solow's steady-state equation (1956),

$S_{i} q_{i t}=\left(n_{i}+\delta\right) K_{i t}$,

where $S$, the savings rate, $n$, the exogenous rate of population growth, and $\delta$, the depreciation rate, are assumed to be variable across countries, but fixed over time.

In the steady state, $k_{i t}=\beta_{i} q_{i t}$, where $\beta_{i}=[s /(n+\delta)]_{i}$ and may include other fixed factors that determine the capital-output ratio. Substituting this steadystate value of $k$ into equation (1) and simplifying gives:

$q_{i t}=\beta_{i} \alpha /(1-\alpha) A_{i t} 1 /(1-\alpha)$.

Differentiating with respect to time yields the following equation, which conveys the core message of Solow's neoclassical growth model:

$(d q / q)_{i t}=\{1 /(1-\alpha)\}(d A / A)_{i t}$.

This model is consistent with Solow's model in that it attributes capital accumulation in the steady state to rising productivity. Equation (3) embodies this insight that raising productivity increases incomes and the supply of savings available for capital deepening; it also shifts out capital's marginal productivity schedule, thus, increasing the demand for investment. Through this continuous outward shift in the supply of savings and demand for investment, sustained productivity growth translates into sustained capital deepening and rising living standards.

Moreover, Mankiew, Romer and Weil (1992) extended Solow'smodel by introducing human capital, in addition to physical capital and raw labor, as the third factor of production. Their modification increased the impact on output of a change in the saving rate for physical capital because increased output induces greater investment in human capital. Therefore, equation (3) can be interpreted as a process in which rising productivity translates into a greater demand for both physical and human capital. 
As in Wu, Cai and Jefferson (2013), we complement the Solow's equation (2) of the neoclassical growth model with a third equation that models the evolution of technological change. This is consistent with the endogenous growth literature in which the long-run growth rate of output per work is determined by various variables within the model, as follows:

$(\mathrm{d} A / A)_{i t}=h\left(I P R_{i t}\right)$,

where $I P R$ is a measure of level of intellectual property rights of country $i$. This model, specifically, enables a test of the role of IPRs protection as one of the channels for promoting technological advance and then economic growth. By substituting gross domestic product per capita, $\left(Y_{i t}\right)$, for $q$, converting

to natural logs, i.e., converting $\mathrm{d} q / q$ to $\ln (q+1)$, equation (3) can be rewritten as:

$\ln Y_{i t i t}=\alpha_{0}+\lambda_{i}+\alpha_{1} \ln G D P P+I P R_{i t}+\mu_{i t}$.

Equation (5) frames the base of the estimation equation that we will use in this study. In equation (5), $\lambda_{i}$ is a vector of fixed effects, which includes those that drive productivity change and other factors that may determine GDPP $\left(Y_{i t}\right)$. Equation (5) is helpful in highlighting the main factors affecting the economic growth of OPEC countries. It is standard in the empirical literature on economic growth to include, at least, one proxy for each of the basic determinants of growth variables. Considering the standard growth decompositions of equation (5), the proposed estimated econometrical regression is as follows:

$$
\ln Y_{i t}=\beta_{i t}+\beta 1 \bar{Y}_{i t}+\beta 2 I N F_{i t}+\beta 3 I P R s_{i t}+\beta 4 P O P_{i t}+\beta 5 H U M_{i t}+\beta 6 O P E N_{i t}+\beta 7 I N V_{i t}+u_{i}+v_{i}+\varepsilon_{i t} .
$$

In this relationship, for country $i$ in time period $t, Y$ indicates per capita GDP; $\bar{Y}$ shows the initial level of per capita GDP at the beginning of the sample period; INF is the inflation rate; IPRs is the intellectual property rights index; $P O P$ indicates the population growth rate; $H U M$ is a measure of human capital; OPEN is trade openness; INV represents the investment-GDP ratio; $\varepsilon_{i t}$ is the error term; and $u$ and $v$ are country- and time-specific effects, respectively.

3.2. Data description. The analyses in this study utilize panel data from cross-sectional data on all OPEC countries for which IPRs data are available. The countries included are Algeria, Angola, Ecuador, Iran, Iraq, Nigeria, Saudi Arabia and Venezuela. The data span five decades (1960-2010), based on the availability of the IPRs measure in use, which is the updated version of the Ginarte and Park index (Park, 2008) ${ }^{1}$. The index incorporates the effects of recent national and global developments, such as amendments to national patent laws and adoption of international treaties, consequently, yielding variability in the measurement of IPRs across countries and over time.

All other explanatory variables (initial GDP per capita, inflation, human capital, population, openness, and investment) are from the World Bank's World Development Indicators (2012).

The initial level of per capita GDP $(\bar{Y})$ is used to predict the level of development and level of convergence, and it is expected to have a negative sign. The inflation rate $(I N F)$ is included to measure economic stability and is expected to have a negative effect on economic growth. Trade openness $(O P E N)$ is

\footnotetext{
${ }^{1}$ Professor Park (the co-author of the index) provided us with the IPRs index up to 2010 by email, as the latest published update of the index was only up to 2005 .
}

a proxy for economic openness and is measured by the sum of the exports plus imports to GDP; it is expected to be positively related to economic growth. Population $(P O P)$ is expected to be inversely related to economic growth. Investment (INV) shows the production of new goods and services, and is expected to positively affect economic growth. Human capital (HUM), as measure by secondary school enrolment, is expected to be positively related to economic growth.

\section{Estimation strategy and empirical results}

4.1. Choice of the estimator. Prior to the estimation of equation (6), it is important to briefly discuss the popular alternative estimation procedures that might be used for this study, namely the pooled ordinary least squares (POLS), the fixed effect model (FE), the random effect model (RE) and the Hausman and Taylor (HT) instrumental variable estimation.

The POLS estimation is likely be more efficient because of the increased number of observations, but the estimation results would be biased, because POLS assumes that there are neither significant country (individual) nor significant temporal effects. In the context of this study, this means that all OPEC member countries in the sample react in the same way to changes in all explanatory variables, which is quite a difficult assumption to accept.

The choice between FE and RE estimators has always been a debatable issue among econometricians. The FE estimator assumes that all the explanatory variables are related to the individual effects, and it is unbiased once the individual effects are modeled as a linear function of all the explanatory variables. Unfortunately, the FE model suffers from two important defects. Firstly, it drops out all time-invariant variables from the 
model (which is not important for this study, as there are no time-invariant variables). Secondly, it utilizes only the variations within countries, ignoring the variations between countries in the sample: it ignores the differences in the levels of variables between countries, and this is quite problematic. However, the RE model assumes no correlation between the explanatory variables and the individual effects. In the present study, it is not appropriate to assume that the individual effects and the regressors are not correlated. Thus, RE will yield a biased estimate and, hence, inferences from the RE model are likely to be misleading random individual effects.

Hausman and Taylor (1981) proposed a model in which some, though not all, of the regressors are correlated with the individual effects. The Hausman-Taylor (HT) model, thus, bridges the two extremes of all (i.e., FE) or nothing (i.e., RE) levels of correlation between the individual effects and the regressors. As Baltagi, Bresson and Pirotte (2003) argued, the HT model is preferable whenever the model requires some, though not all, of the regressors to be correlated with the individual effects, which is the case in this study.

Given the above discussion, we are inclined to use the HT estimator, and our choice is also supported by the fact that there are several studies of economic growth that have used HT in their empirical estimation. Examples include McPherson and Trumbull (2008), Agbor (2011) and Paudel (2014). In summary, in this study, the choice to use the HT estimator is made owing to its advantages over other possible estimators. Firstly, HT uses the individual time averages of the strictly exogenous variables as instruments for the time-invariant variables that are correlated with the individual effects. Thus, this procedure allows for the simultaneous control of the correlation between regressors and unobserved individual effects by using instruments. Secondly, it avoids the insecurity associated with the choice of suitable instruments, since the individual means over time of all the included regressors can serve as valid instruments. Finally, it can take into account the dynamics of the long time period covered by the dataset in this study, namely 1960-2010 (for more details, refer to Hausman and Taylor (1981), Wooldridge (2002) and Baltagi, Bresson and Pirotte (2003)).

4.2. Empirical results and discussion. The overall results of HT estimation of the base model, as shown in Table 1, conform to prior expectations and can be interpreted as offering empirical validation for the theoretical explanatory variables that have been suggested in the economic growth literature.
Table 1. Hausman-Taylor estimation result

\begin{tabular}{|c|c|c|}
\hline \multirow{3}{*}{ Explanatory variables } & \multicolumn{2}{|c|}{$\begin{array}{l}\text { Dependent variable: growth rate of GDP } \\
\text { per capita }\end{array}$} \\
\hline & $\begin{array}{l}\text { Base model } \\
\text { (1) }\end{array}$ & $\begin{array}{l}\text { Model } \\
(2)\end{array}$ \\
\hline & HT estimation & With interaction effects \\
\hline Constant & $\begin{array}{c}28.32^{* * *} \\
(4.12)\end{array}$ & $\begin{array}{c}27.65^{\star \star *} \\
(3.53)\end{array}$ \\
\hline $\bar{Y}_{i t}$ & $\begin{array}{l}-0.834^{*} \\
(-5.81) \\
\end{array}$ & $\begin{array}{l}-1.20^{*} \\
(-4.76) \\
\end{array}$ \\
\hline$I N F_{i t}$ & $\begin{array}{c}-0.863^{*} \\
(-1.9)\end{array}$ & $\begin{array}{l}-0.933^{* *} \\
(-1.02)\end{array}$ \\
\hline POP it & $\begin{array}{c}-0.18 \\
(-0.012) \\
\end{array}$ & $\begin{array}{l}-2.11 \\
(-0.91) \\
\end{array}$ \\
\hline HUMit & $\begin{array}{l}0.09^{*} \\
(2.45)\end{array}$ & $\begin{array}{c}0.13^{*} \\
(1.99)\end{array}$ \\
\hline OPEN & $\begin{array}{l}6.95^{* * *} \\
(2.99)\end{array}$ & $\begin{array}{l}5.87^{* *} \\
(2.11)\end{array}$ \\
\hline$I N V_{i t}$ & $\begin{array}{c}0.09 \\
(0.11)\end{array}$ & $\begin{array}{c}0.07 \\
(0.02)\end{array}$ \\
\hline IPRsit & $\begin{array}{c}0.07 \\
(0.01)\end{array}$ & - \\
\hline$I P R s_{i t}^{*} O P E N_{i t}$ & - & $\begin{array}{c}2.64 \\
(1.02)\end{array}$ \\
\hline R-square & 0.68 & 0.63 \\
\hline F-statistics & $18.1^{* \star}$ & $19.0^{* \star}$ \\
\hline
\end{tabular}

Notes: $t$-statistics are given in parentheses. $*, * *, * * *$ indicate that the given variable is statistically significant up to the $10 \%$, $5 \%$ and $1 \%$ level of significance, respectively; otherwise, the variable is statistically insignificant.

The signs and/or significance of explanatory variables of the base model are generally as expected, except for the IPRs and physical investment, which are positive but not significant; the statistical insignificance of these variables may be due to their collinearity with other explanatory variables in the model, or with other "omitted" country-specific characteristics that are not part of the explanatory variables. Otherwise, the initial GDP per capita is negative and significant, confirming the convergence hypothesis; population has a negative sign, as expected, and is significant; trade openness prompts economic growth with the expected positive sign; secondary school enrolment, which is used as a proxy for investment in human capital, is also significant and has the expected positive sign. However, the main concern of this study is the IPRs variable, which was not statistically significant; this implies that the IPRs variable does not play a role in determining the economic growth of OPEC countries.

This might be explained by the fact that IPRs are not directly related to economic growth, which is a similar result to those found in previous studies, such as Wu (2010) and Samuel (2011). Therefore, we re-run Model 1 and called it Model 2; Model 2 includes an interaction term for both IPRs and trade (using the OPEN variable), which appear in the last column of Table 1 . The results of the interaction 
term were positive and statistically significant, which implies that IPRs and trade regimes exerta robust impact on the economic growth of OPEC countries, whereas IPRs themselves do not drive the economic growth of OPEC. The policy implication of this finding is that trade liberalization augmented with strong IPRs plays an important role in the economic growth of OPEC countries.

To ensure the robustness of the estimates, several diagnostic tests on the chosen model in this study are performed. These included testing for heteroskedasticity using the Breusch-Pagan and Cook-Weisberg tests; multicollinearity test using correlation matrix and variance inflation factor (VIF); normality test using skewness/kurtosis test and normality graphs; model specification test using link specification test; and omitted variables test using Ramsey RESET test. All results show that the chosen models of economic growth are well specified, except where heteroskedasticity is exhibited, and this problem has been corrected by using robust standard errors.

\section{Conclusion}

The main objective of this study was to empirically explore the relationship between IPRs protection and the economic growth of OPEC member countries.
The findings largely confirm the prior expectations relating to "traditional" sources of economic growth, as postulated in the economic growth theories, in terms of convergence hypothesis, population growth and trade openness and others; these are in line with the findings of many studies, such as Barro and Sala-i-Martin (1995), Sinha and Sinha (2007), and others. However, the study did not find any empirical validation with respect to the role of IPRs in promoting economic growth in the OPEC member countries. The insignificant relationship between IPRs and economic growth in the case of OPEC countries may be related to the fact that OPEC countries can exhibit the character of "rentier states", in which IPRs per se are not sufficient to ensure technological progress and innovation. However, when the IPRs variable is interacted with the trade variable, the interaction term is statically significant, which implies that IPRs promote the economic growth of OPEC countries indirectly through trade channels.

Depending on the availability of data, future research may look at the factors underling the IPRsgrowth nexus for resource-rich countries other than oil countries and compare the results with the findings of the present study to ratify our results, or otherwise.

\section{References}

1. Abubaker, M., Agayey, F. and Ilkan, M. (2013). Energy Demand Interplay with Real GDP and Oil Prices, Advances in Management \& Applied Economics, 3 (4), pp. 95-104.

2. Agbor, J. (2011). How Does Colonial Origin Matter for Economic Performance in Sub-Saharan Africa. Working Paper No. 2011/27, World Institute for Development Economic Research, United Nations University.

3. Andrés, R. and Goel, K. (2011). Corruption and Software Piracy: A Comparative Perspective, Policy \& Internet, 3 (3), pp. 1-22.

4. Baltagi, B., Bresson, G. and Pirotte, A. (2003). Fixed effects, random effects or Hausman-Taylor? A pretest estimator, Economics Letters, 79, pp. 361-369.

5. Barro, R. and Sala-i-Martin, X. (1995). Economic Growth. New York: McGraw Hill.

6. Boldrin, M. and Levine, D. (2009). Against Intellectual Monopoly. Cambridge, UK: Cambridge University Press.

7. Boone, J.P. (2001). Empirical evidence for the superiority of non-US oil and gas investments, Energy Economics, 23, pp. 211-226.

8. Buno, M., and J. Sachs. (1982). Input Price Shocks and the Slowdown in Economic Growth: The Case of U.K. Manufacturing, Review of Economic Studies, 49, pp. 679-705.

9. Dinopoulos, E. and Segerstrom, P. (2010). Intellectual property rights, multinational firms and economic growth, Journal of Development Economics, 92, pp. 13-27.

10. Eicher, T. and Newiak, M. (2013). Intellectual property rights as development determinants, Canadian Journal of Economics, 46 (1), pp. 4-22.

11. Falvey, R., Foster, N. and Greenaway, D. (2006). Intellectual Property Rights and Economic Growth, Review of Development Economics, 10, pp. 700-719.

12. Furukawa, Y. (2007). The protection of intellectual property rights and endogenous growth: Is stronger always better? Journal of Economic Dynamics \& Control, 31, pp. 3644-3670.

13. Ghalayini, L. (2011). The interaction between Oil price and Economic Growth, Middle Eastern Finance and Economics, 13, 27-141.

14. Ginarte, C. and Park, W. (1997). Determinants of Patent Rights: A Cross-National Study, Research Policy, 26, pp. 283-301.

15. Gould, D.M. and Gruden, W.C. (1996). The role of intellectual property rights in economic growth, Journal of Development Economics, 48, pp. 323-350.

16. Grossman, G. and Helpman, E. (1991). Trade, knowledge spillovers, and growth, European Economic Review, 35 (2-3), pp. 517-526.

17. Gulen, S. (1996). Is OPEC a cartel? Evidence from cointegration and causality tests, Energy Journal, 17 (2), pp. 43-57. 
18. Hassan, E., Qaqub, O. and Diepeveen, S. (2010). Intellectual Property and Developing Countries: A review of the literature, Technical Report, the RAND Research Corporation, UK.

19. Hausman, A.J. and Taylor, E.W. (1981). Panel Data and Unobservable Individual Effects, Econometrica, 49, pp. 1377-1398.

20. Helpman, E. (1993). Innovation, imitation, and intellectual property rights, Economica, 61 (6), pp. $1247-1280$.

21. Hook, A. and Aleklett, K. (2008). A decline rate study of Norwegian oil production, Energy Policy, 36, pp. $4662-4671$.

22. Horii, R. and Iwaisako, T. (2007). Economic Growth with Imperfect Protection of Intellectual Property Rights, Journal of Economics, 90 (1), pp. 45-85.

23. Hudson, J. and Minea, A. (2013). Innovation, Intellectual Property Rights, and Economic Development: A Unified Empirical Investigation, World Development, 46 (c), pp. 66-78.

24. Iwaisako, T. and Futagmi, K. (2003). Patent policy in an endogenous growth mode, Journal of Economics, 78 (3), pp. 239-325.

25. James, A. (2015). The resource curse: A statistical mirage? Journal of Development Economics, 14, pp. 55-63.

26. Kanwar, S. and Evenson, R. (2003). Does intellectual property protection spur technological change? Oxford Economic Papers, 55 (23), pp. 5-264.

27. Karbassi, A.R., Abdul, M.A. and Abdollahzadegh, E.M. (2007). Sustainability of energy production and use in Iran, Energy Policy, 35, pp. 5171-5180.

28. Koléda, G. (2005). Northern and Southern Patent Novelty Requirements Harmonization, Growth and Trade. DEGIT Conference Papers c010_025, DEGIT, Dynamics, Economic Growth, and International Trade.

29. Kwan, K. and Lai, E. (2003). Intellectual Property Rights Protection and Endogenous Economic Growth, Journal of Economic Dynamics \& Control, 27, pp. 853-873.

30. Lean, H.H. and Smyth, R. (2009). Long memory in US disaggregated petroleum consumption: evidence from univariate and multivariate LM tests for fractional integration, Energy Policy, 37, pp. 3205-3211.

31. Lerner, J. (2009). The Empirical Impact of Intellectual Property Rights on Innovation: Puzzles and Clues, American Economic Review, 99 (2), pp. 343-348.

32. Liu, M., Ji, Q. and Fan, Y. (2013). How does oil market uncertainty interact with other markets? An empirical analysis of implied volatility index, Energy, 55 (15), pp. 860-868.

33. Mankiw, N., Romer, D. and Weil, N. (1992). A Contribution to the Empirics Growth, Quarterly Journal of Economics, 107, pp. 407-437.

34. Maskus, E. (2000). Intellectual Property Rights and Economic Development, Case Western Journal of International Law, 32, pp. 471-506.

35. Maskus, K.E. and Penubarti, M. (1995). How trade-related are intellectual property rights? Journal of International Economics, 39 (3-4), pp. 227-248.

36. McLennan, P. and Le, Q. (2011). The effects of intellectual property rights violations on economic growth, Modern Economy, 2 (2), pp. 107-113.

37. McPherson, M. and Trumbull, W. (2008). Rescuing Observed Fixed Effects: Using the Hausman-Taylor Method for Out-of-Sample Trade Projections, The International Trade Journal, 22 (3), pp. 315-340.

38. Mohn, K. and Osmundsen, P. (2008). Exploration economics in a regulated petroleum province: the case of the Norwegian Continental Shelf, Energy Economics, 30, pp. 303-320.

39. Park, W.G. (2008). International Patent Protection: 1960-2005, Research Policy, 37, pp. 761-766.

40. Paudel, R. (2014). Economic Growth in Developing Countries: Is Landlockedness Destiny? Working Paper No. 2014/01, Arndt-Corden Department of Economics Crawford School of Public Policy, Australian National University, Australia.

41. Rivera-Batiz, A. and Romer, M. (1991). International trade with endogenous technological change, European Economic Review, 35 (4), pp. 971-1001.

42. Romer, P.M. (1990). Endogenous Technological Change, Journal of Political Economy, October, 98 (5), pp. $71-102$.

43. Samuel, A. (2011). Intellectual property rights, innovations, and economic growth in Sub-Saharan Africa, Journal of Third World Studies, 28, Issue 1, p. 231.

44. Sattar, A. and Mahmood, T. (2011). Intellectual property rights andeconomic growth: Evidences from high, middle and low income countries, Pakistan Economic and Social Review, 49 (2), pp. 163-186.

45. Sinha, D. and Sinha, T. (2007). Toda and Yamamoto causality tests between per capita saving and per capita GDP for India. MRPA Paper No. 2564, 04 January.

46. Smith, P. (1999). Are weak patent rights a barrier to US exports? Journal of International Economics, 48 (1), pp. 151-177.

47. Thompson, M. and Rushing, F. (1999). An Empirical Analysis of the Impact of Patent Protection on Economic Growth: An Extension, Journal of Economic Development, 24 (1), pp. 67-76.

48. Tsoskounoglou, M., Ayerides, G. and Tritopoulos, E. (2008). The end of cheap oil: current status and prospects, Energy Policy, 36, pp. 3797-3806.

49. World Bank. (2012). World Development Indicators. Washington, DC: World Bank.

50. World Bank. (2014). World Development Indicators. Washington, DC: World Bank.

51. Wooldridge, J.M. (2002). Econometric Analysis of Cross Section and Panel Data. Cambridge, MA: MIT Press.

52. Wu, H. (2010). Distance to frontier, intellectual property rights, and economic growth, Economics of Innovation and New Technology, 19 (2), pp. 165-183.

53. Wu, K., Cai, H. and Jefferson, G. (2013). Trade and intellectual property rights as channels for economic growth, Asia-Pacific Journal of Accounting and Economics, 20 (1), pp. 20-36. 